UDC 616.2:316-092.9:579.861.2

S. V. KALINICHenKo ${ }^{1,2}$, O. O. KorotKYKH ${ }^{1}$, I. YU. TishCHENKO ${ }^{2}$

${ }^{1}$ SI "Institute of Microbiology and Immunology I. I. Mechnikov National Academy of Medical

Sciences of Ukraine"

${ }^{2}$ National University of Pharmacy

\title{
MICROECOLOGICAL DISORDERS AND THEIR MODERN CORRECTION (REVIEW)
}

The need to adjust the balance of microbiocenosis - this problem is modern and relevant. It was considered a wide range of drugs (products) that affect different parts microecological process: probiotics, preparations based on inactivated microorganisms, prebiotics, sinbiotics, drugs metabolic type, functional food, nutraceuticals. The mechanisms of their action have been analyzed and proved, as well as urgency and prospects of the known and new drugs that affect endoecology and update it.

Key words: microflora; microecology; probiotics; prebiotics; synbiotics; nutraceuticals; biotherapy; functional food

In theory, the concept of Microecology and Endoecology exists for a long time, and it were first described by our compatriot, the famous scientist, the Nobel Prize winner for the discovery and creation of phagocytosis theory of immunity - Ilya Mechnikov, who carried out a study of the intestinal microflora recovery possibility by using lactic acid bacillus Lactobacillus delbrueckii subsp. bulgaricus and found a positive effect against lactic acid bacteria on the human body [17]. Recognition of ideas Mechnikov focused on changing the composition of microflora in the gastrointestinal tract by enteral cultures of lactic acid bacteria as antagonists putrefying microbes led to the development of such areas as "biotherapy" and led to the creation of a new class of bacterial preparations probiotics, and further and prebiotic and synbiotic.

World Gastroenterology Organisation (WGO, 2008) gives the following definition [16]: probiotics - live microorganisms which when administered in adequate amounts carry a positive effect on the host organism; prebiotics substances that are not absorbed and have a positive physiological effect on the host by selectively stimulating the growth or activity of the necessary intestinal flora; synbiotics - products containing pro- and prebiotics.

Preparations (products) to restore normal microflora distributed as follows (Starovoitova S. 0.) [22] (Table).

\section{Probiotics}

For the first time the term "probiotic" was used in 1953 by the German bacteriologist, hygienist and nutraceutical collaterals Werner (1892-1970) for the determination of organic and inorganic ingredients necessary for restoring the health of patients suffering from a form of malnutrition as a result of the introduction of the diet of excessive amounts of high-purity products.

o) Kalinichenko S. V., Korotkykh O. O., Tishchenko I. Yu., 2016
Over the years there were several interpretations of the term "probiotic" $[7,30]$ :

- US vets Daniel M. Lilly and Rosalia G. Stillwell (1965): Probiotics - a microbial metabolites that stimulate the growth of microorganisms;

- Italian-American scientist George Spero stale (1971): Probiotics - are extracts of any tissue that stimulate the growth of microorganisms;

- $\quad$ English scientist R. B. Parker (1974): Probiotics - a microbial drugs that regulate microbial ecology of the digestive tract;

- English expert in the field of microbial ecology Roy Fuller (1989): Probiotics - are preparations of living microorganisms exercising macroorganism beneficial effect due to the correction of the intestinal microflora;

- Roy Fuller (1995): Probiotics - are preparations of live microorganisms or microbial growth promoters, animal or vegetable origin, carry out a beneficial effect on the indigenous microflora;

- $\quad$ English professor of food microbiology Glenn R. Gibson and Belgian professor medical Roberfroyd Marseille (1995): probiotics - dietary supplements is of microbial origin, showing their positive properties in the macro-organism through the regulation of intestinal microflora;

- Canadian professor of microbiology and immunology Gregor Reid (2003): Probiotics - are live microorganisms, the use of which results in adequate doses to improve host health;

- The Russian scientist B. A. Shenderov, head of probiotics and functional food products Institute of Epidemiology and Microbiology named Gabrichevskogo: probiotics - live microorganisms and substances of microbial origin, in the natural method of admini- 


\section{PREPARATIONS (PRODUCTS) TO RESTORE NORMAL MICROFLORA DISTRIBUTED AS FOLLOWS (STAROVOITOVA S. 0.)}

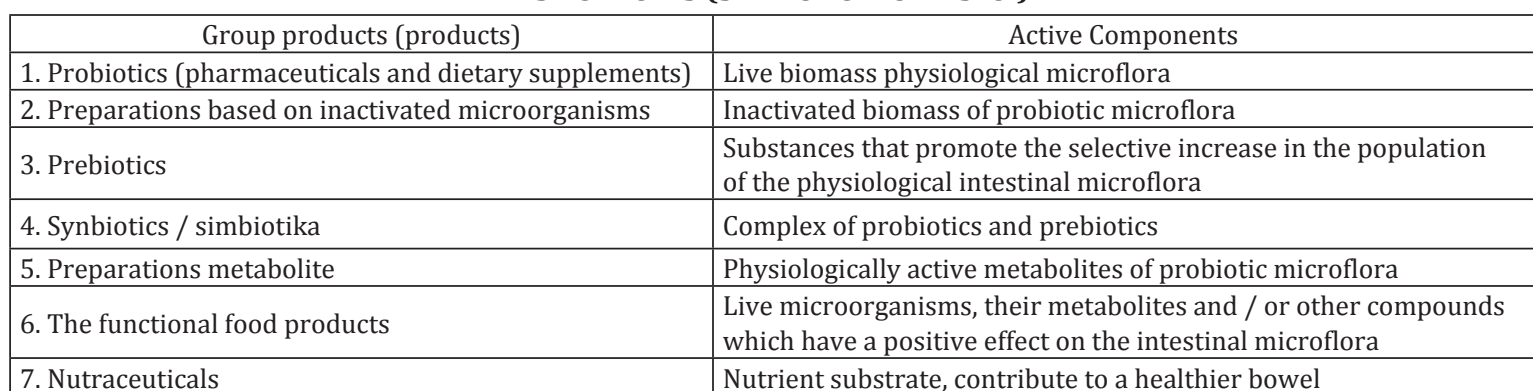

stration produce positive effects on physiological, biochemical and immune response of the host (human or animal) as a result of optimization and stabilize its microbiota. The term "probiotic" is defined as an antonym to antibiotics, ie, "a promoter of life". Large role of probiotics in the correction of microecological processes was considered by us in the previous article 'The topical areas of creation and improvement of probiotics", so now we prefer the analysis of other groups of drugs and products for restoring or balancing of the normal human microbiocenosis.

\section{Prebiotics}

The term "probiotics" was first applied an English professor in the field of food microbiology R. Gibson, who replaced the prefix "pro" to "pre", meaning "for". Now the term is used to determine the origin of non-microbial agents that can have a positive effect on the human body through a selective stimulation of growth or metabolic activity of the normal microflora $[7,11,30]$. That is, prebiotics substances that selectively stimulate the growth and enhance the metabolic processes of the normal microflora (particularly bifidobacteria and lactobacilli). They improve a variety of physiological functions and metabolic reactions associated with the functioning of the symbiotic microflora (resistance to infections, reduced risk of malignant tumors, improving the bioavailability of calcium and magnesium, the colonization of the intestine of infants beneficial microorganisms, reducing serum cholesterol, etc.). The greatest amount of prebiotic substances contained in natural foods.

By origin are prebiotics (by Levitsky A. P. et al.) [11]:

1. Plant (fitoprebiotiks): inulin and fruktooligosaccharides (FOC); A-galaktooligotsaccharides (MCC); B-glycans (dietary fiber); resistant starches; vitamins; fitolizotsim; inhibitors of Fr.; EAZ and amylase.

2. Animal origin (zooprebiotiks): oligosaccharides of milk; glycopeptides of milk; lactoferrin; oligopeptides; amylase inhibitors and proeaz; lysozyme.

3. Artificial: lactulose; modified starches.

B. A. Shenderov and colleagues analyzed the substances that can stimulate the growth of normal microflora, prebiotics and divided into the following groups [30]:

- Monosaccharides and alcohols (xylitol, melibiose, xylose, xylobiose, raffinose, sorbitol, etc.);
- Oligosaccharides (lactulose, latsitol, soy oligosaccharide latitololigosaharid, fructooligosaccharides, galactooligosaccharides, isomaltooligosaccharides, diksilooligosaharid et al.);

- $\quad$ Polysaccharides (pectin, pululan, dextrin, inulin, chitosan, $\beta$-glucans, etc.);

- $\quad$ Enzymes ( $\beta$-galactosidase of microbial origin, and proteases of Saccharomyces al.);

- Peptides (soy, and dairy al.);

- Amino acids (valine, arginine, glutamic acid, etc.);

- Antioxidants (vitamins, vitamin E, ascorbic acid, $\alpha$-, $\beta$-carotene, other carotenoids, glutathione, Ubiquinol, selenium salts, etc.);

- The unsaturated fatty acids (eicosapentaenoic acid);

- Organic acids (propionic acid, acetic acid, citric acid and others);

- Plant and microbial extracts (carrot, potato, corn, rice, pumpkin, garlic, yeast and others);

- Others (lecithin paraaminometilbenzoic acid, lysozyme, lactoferrin, gluconic acid, glucose syrup, pectins of different origin, etc.).

Specific requirements exist for the selection of prebiotics for medicines [7]:

- They should not be cleaved by enzymes microorganism,

- Do not be absorbed in the upper part of the small intestine;

- Must be a selective substrate for the indigenous microflora;

- Should improve the condition and prevent the development of microbiocenosis dysbiotic violations;

- Should have a positive impact on the macroorganism.

Therefore, poly- and oligofruktants, soybean oligosaccharides, galacto-oligosaccharides isolated from natural sources or produced synthetically or by biotechnological methods currently in use. For creating prebiotic drugs most commonly used $[11,30]$ :

oligosaccharides, including $\mathrm{N}$-acetylglucosamine, glucose, galactose, oligomers, fucose or other glycoproteins, which constitute a significant proportion of breast milk, and are specific for growth factors for bifidobacteria;

lactulose - a synthetic disaccharide, which is a nutrient substrate for bacteria and saccharolytics over 40 years is applied for stimulation of growth of lactobacilli in newborns. In the process of bacterial degradation of 
lactulose on short chain fatty acids (lactic, acetic, propionic, butyric) decreases the $\mathrm{pH}$ of the colon contents. This increases the osmotic pressure, accompanied by fluid retention in the lumen of the intestine and increasing its peristalsis. Use of lactulose leads to increased bacterial mass is accompanied by an active utilization of ammonia nitrogen and amino acids. These changes are responsible for the preventive and therapeutic effect of lactulose for constipation, portosystemic encephalopathy, bacterial enteritis (Salmonella enteritidis, Yersinia, Shigella), diabetes and other pathologies;

inulin - fruktozane polysaccharide, hydrolysis of which glucose is formed. Contained in the roots and tubers of dahlia, Jerusalem artichoke, artichoke and dandelion. Besides stimulating the growth and activity of bifidobacteria and lactobacilli improves calcium absorption in the large intestine, reducing the risk of osteoporosis affects lipid metabolism, reduces the risk of atherosclerotic lesions in the cardiovascular system and prevents the development of type II diabetes, the data on its anti-carcinogenic effect;

fructooligosaccharides are not digested by enzymes microorganism and hardly absorbed in the upper gastrointestinal tract. Selection stimulate growth of bifidobacteria and inhibit the growth of clostridia and fuzobakteria enhance absorption of calcium, magnesium, iron and zinc, to reduce the concentration of cholesterol;

galactooligosaccharides contained in milk, soybeans and other plants. Stimulate the growth of bifidobacteria and other anaerobes do not affect the number of aerobic. Increases the resistance of bifidobacteria in the acidic environment of the stomach;

resistant starches - starches are difficult digested in the small intestine. Their amount in the food ranges from 0 to $25 \%$. Contain substantial amounts of oligosaccharides, particularly izomaltosaharidy that are not cleaved glyukozamilazoy. Lowers after food hyperglycemia, stimulate the growth of bifidobacteria, contribute to the formation of organic acids, enhance immunity, reduce the risk of inflammation and malignant neoplasms, acting as enterosorbents.

Starches are divided into 4 classes:

RS1 - physically inaccessible starches inside the plant cells or crushed grains;

RS2 - native banana, corn and wheat starches with a high content of amylase;

RS3 - crystal, which are formed by retrogradation gelatinized starch;

RS4 - specific chemical modification starches;

dietary fiber - structure are biopolymers (cellulose, hemicellulose, pectin, lignin, chitin, chondroitin, collagen, elastin, etc.). Have the properties of the sorbent (adsorb the sterols, bile acids, toxins, bacteria). They belong to the polysaccharides. The most valuable for the development of anaerobic flora is pectin, because the microbial decomposition of its metabolites are formed, such as acetic and propionic acid. Dietary fibers are divided into three groups:

1) fiber assimilated by bacteria (pectin, water-soluble high-viscosity polysaccharides which are composed of glucose, galactose, mannose, arabinose, rhamnose and uronic acids), and polysaccharides from linseed, seaweed;

2) fibers partially metabolized by bacteria (cellulose, hemicellulose);

3) fiber is not digested by microorganisms (lignin).

The physiological effects of dietary fiber:

- Keeps the water, increasing the osmotic pressure in the lumen of the gastrointestinal tract (GIT), weight and volume of feces, normalize electrolyte composition of the intestinal contents, resulting in gastrointestinal motility;

- Have a high sorption activity, which explains their pronounced detoxifying effect;

- Colonic microflora, which assimilates fiber, receives energy and plastic material for the growth and proliferation;

- VFA (volatile fatty acids), formed as a result of vital activity of the microflora essential for proper functioning and repair colonocytes.

The daily requirement for dietary fiber is 20-35 grams, but the average European actually gets them no more than 13 grams, which can lead to a number of pathological conditions: varicose veins and thrombosis of the lower limbs, coronary heart disease, cholelithiasis, diabetes, obesity, irritable bowel syndrome, constipation, colon cancer and others.

In addition to these, as prebiotic substances are also used various adhesion blockers and inhibitors of the growth of pathogenic and opportunistic microorganisms (lectins antiadgesic modulators of secretory immunoglobulin synthesis, any type of defensins, the structural components of probiotic microorganisms and their metabolites, etc.).

\section{Synbiotics}

The combination of probiotics with prebiotic substances led to the creation of new biologically active compounds "synbiotics" in which living organisms are combined with substrates that stimulate their growth $[22,39]$. However, these drugs are regarded as the synbiotics possible only if all living or dead microorganisms, their structural components, metabolites, which positively influence the functioning of the host microflora contribute to better adapt them to environmental conditions in a particular ecological niche. That is, in the composition of prebiotic preparations should not be included in the metabolism of a microorganism serve as a starting component of its growth.

Thus, synbiotics - a drug, which are obtained by using a rational combination of probiotics and prebiotics.

According to the WHO predicted that by 2020 the world production of these products reach hundreds of thousands of tons [7].

Biological preparations based on metabolites, and structural components of microbial cells

For medicines based on metabolites, and structural components of microbial cells include drugs [22, 39]:

- The metabolite type - created on the basis of complex physiological metabolic products of microorganisms 
perform a major role in maintaining homeostasis microecological in human habitats. The main attention is paid to the synthesized normal flora, volatile fatty acids, especially butyric, propionic and acetic.

For example, "Hilak forte" - extract metabolic products of lactobacilli, enterococci, E. coli and with the addition of phosphoric and lactic acids and mineral substances.

Probiotics type metabolite obtained on the basis of a set of chemically synthesized substances known. They simulate metabolites saccharolytic indigenous microflora: for the treatment of infectious diseases of the oral cavity, caused by certain toxins - «Solkarmon» which enhances the repair of the epithelium and blocks the adhesion of pathogenic gram-positive microflora and bacteriostatic activity against staphylococci and streptococci; bowel disease - "Frodo", which contains a variety of substances (butyric acid, acetic acid, propionic acid, propionate, acetate etc.) covering the deficiency of low molecular weight automikroflora dysbacteriosis metabolites. It is also noted that the preliminary intra-administration of the drug, "Frodo" laboratory animals in experimental modeling of peritonitis and colitis twice reduced the $\mathrm{LD}_{50}$.

- On the basis of the structural components of cells structural components contain cells of Lactobacillus srp., Most commonly Lactobacillus bulgaricus (L. delbrueckii ssp. Bulgaricus). These preparations possess immunomodulatory properties ("Deodan", "Blasten") and capable of increasing anti-tumor immunity of cancer patients ("Blastolizin").

Biological preparations based on inactivated biomass of probiotic microflora

First of all it preparations based on inactivated cells of lactic microflora $[22,39]$. Their action is based on inhibition of the adhesive properties of potentially hazardous microflora by screening inactivated probiotic cells specific receptors on the epithelium. It was established that for the manifestation of efficacy antagonistic inactivated probiotic it is necessary to use a ten-fold volume compared to the preparations on the basis of live microorganisms. Probably, the main effect of inactivated probiotic cells is a stimulating effect on the immune system because they are a powerful source of immunogenic compounds such as peptidoglycan.

Preparations on the basis of a set of live flora and biologically active components, functional food products

Double Nobel prize winner Linus Pauling first proposed to consider food and their individual components as pharmaceuticals. He has developed and actively implemented the concept of the health effects of functional food, which is based on the fact that biologically active film covering the mucous membranes of the digestive tract of habitat is the primary target for any food substrate that enters the body orally [22, 30,39]. Therefore, products that have a positive impact on the structure and function of normal microflora, at physiological con- centrations contribute to the improvement of the physical and mental health and reduce the risk of disease.

However, as an independent scientific and applied problems of representation of healthy food concept of "functional food" was formed in the early 90 s. At the same time it developed and terminology, according to which:

Functional food - a special-purpose products of natural or synthetic origin, intended for regular daily consumption that contribute to the replenishment of the lack of energy in the body, plastic or regulatory food substances.

Functional foods - foods designed for the systematic use in the diets of all age categories a healthy population to reduce the risk of diseases related to nutrition, conservation and improvement of health due to the presence in their composition physiologically functional food ingredients.

The functional food ingredient - a compound or complex of substances of animal, vegetable, microbial, or mineral origin identical to natural as well as live microorganisms that have the ability to cause a positive effect on one or more physiological functions metabolism in humans when consumed in amounts of 10-50\% of the daily physiological needs.

The functional food (FF) and dietary supplements (DS) differ only form in which the functional ingredients are delivered in the human body. If the delivery occurs in a similar dosage form for oral administration (tablets, capsules, powders, etc.), it is - DS. If the functional ingredient enters the body in the form of traditional food substance it is a question of FPH.

The difference between probiotics and functional food products is:

- Form in which they enter the body (traditional food preparation or product);

- The concentration of the active ingredient. The probiotics it is usually much higher than the physiologically needed amount, so they are usually designed for use over a limited time. Concentrations of food substances in approximate physiological $\mathrm{FF}$, and so the products can be used for a long time.

It is believed that the food product may be attributed to the functional foods, if the content of certain functional food ingredient is not less than $30 \%$ of its daily requirement.

One of the most essential functional food are milk products. Drink Yakult can be considered the ancestor of functional food industry. It was made in 1955 by the Japanese company Yakult Honsha Group based on powdered milk, water, glucose, sugar, flavoring and Lactobacillus casei.

Several classifications of dairy products exists (like sourdough, raw materials and the composition of its main components, production technology, etc.). The most popular is the classification for the intended purpose for the supply of healthy and sick people, taking into account the functional properties of dairy products, their nutritional and biological value [22, 39]. 
Specialized dietary dairy products are divided into preventive and curative

Preventive include:

1. Dairy products aimed functional activity on the basis of:

- Probiotics with specific physiological and biochemical properties (hypocholesterolemic, anticarcinogenic, antianemic, etc.);

- Prebiotic;

- With a modified composition (e.g., hydrolyzed lactose, for persons with maladsorbtion nutrients).

2. The milk products for diabetics and overweight people (contain artificial sweeteners and/or prebiotics).

3. Dairy products supplemented with immunostimulants and biologically active substances (lysozyme, enzymes, etc.).

4. The dairy products based Consortium probiotics.

5. Dairy products for sportsmen, special contingent (they have modified the composition of macro- and micronutrients).

6. Dairy foods for the elderly.

For therapeutic milk product includes:

1. Dairy-based probiotics (for patients with acute and chronic intestinal infections and patients with diseases of the digestive tract).

2. Dairy products containing probiotics do not contain lactose.

3. Dairy products containing probiotics and hydrolysed proteins (patients allergic diseases).

4. Dairy products for the treatment of other diseases (e.g., cancer patients administered milk products containing live cells L. delbrueckii ssp. Bulgaricus and their structural components).

\section{Nutriceutics}

These dietary supplements that enrich foods to increase their nutritional value. They, like drugs, clinical trials and meet the quality standards adopted in modern pharmacology [22, 39].

Nutraceuticals include $\mathrm{K}$ - vitamins, short chain and medium chain fatty acids, polyunsaturated fatty acids $(\omega-3$ and $\omega$-6), macro- (calcium, phosphorus, sulfur, potassium, sodium, magnesium) and trace elements (zinc, manganese, iron , chromium, selenium, iodine, fluorine, copper, cobalt), amino acids (glutamine, arginine, etc.), mono- and disaccharides, dietary fibers (cellulose, pectin). That is, a substance that the body needs on a daily basis, but does not always work. Physiologically valuable properties are: immunomodulatory, cytoprotective and antioxidant functions involved in metabolic processes, providing epithelial cells of energy and plastic material effect on the hormonal metabolism. The most studied are nutraceuticals glutamine, arginine and other amino acids, short chain and medium chain fatty acids, polyunsaturated $\omega-3$ and $\omega-6$ fatty acids.

\section{CONCLUSIONS}

Thus, there is no doubt that a reasonable use of the aforementioned drugs is an important technique for con- servation and restoration of health. Moreover, given the above, it can be concluded that probiotics - an important component of the global pharmaceutical market, which is estimated at billions of dollars a year.

\section{REFERENCES}

1. Англо-русский глоссарий основных терминов по вакцинологии и иммунизации [Електронний ресурс] // World Health Organization. - 2009. Режим доступу: http://www.euro.who.int/_data/assets/ pdf_file/0013/102172/E92773.pdf

2. Белоусова Е. Л. Saccharomyces boulardii в гастроэнтерологической практике / Е. Л. Белоусова // Гастроэнтерол. - 2009. - № 2. - С. 5-8.

3. Валышев А. В. Микробная экология пищеварительного тракта человека [Текст] / А. В. Валышев, Ф. Г. Гильмутдинова // Экол. микроорганизмов человека / Под ред. О. В. Бухарина. - Екатеринбург: Институт клеточного и внутриклеточного симбиоза, 2006. - С. 169-290.

4. Войда Ю. В. Микроэкология человека и роль пробиотических препаратов в терапии гнойно-воспалительных заболеваний в акушерстве и гинекологии [Текст] / Ю.В.Войда, Н. Л. Солонина // Ann. of Mechnikov Institute. - 2012. - № 2. - C. 27-37. [Електронний ресурс]. Режим доступу: http://archive. nbuv.gov.ua/e-journals/AMI/2012_2/12 vyvmcr.pdf

5. Гайдеров А. А. Изучение свойств штаммов Escherichia coli M-17 и bacillus subtilis 1719 на модели экспериментального дисбиоза [Текст]: автореф. дис. ... канд. биол. наук: 03.00.07 / А. А. Гайдеров. Российский университет дружбы народов. - М., 2007. - 22 c.

6. Иркитова А. Н. Эколого-биологическая оценка штаммов Lactobacillus, используемых в производстве пробиотических продуктов [Текст]: автореф. дис. ... канд. биол. наук: 03.00.07 / А. Н. Иркитова. - Институт экологии и генетики микроорганизмов УрО РАН, Пермь. - 2012. - 22 с.

7. Калініченко С. В. Сучасний стан розробки та застосування пробіотичних, пребіотичних та синбіотичних препаратів (огляд літератури) [Текст] / С. В. Калініченко // Ан. Мечниківського інституту. - 2013. - № 3. - С. 5-12. Режим доступу: http://www.irbis-nbuv.gov.ua/cgi-bin/irbis_nbuv/ cgiirbis_64.exe?Z21ID=\&I21DBN=UJRN\&P21DBN= UJRN\&S21STN $=1 \& S 21 \mathrm{REF}=10 \& S 21 \mathrm{FMT}=$ njuu_al $1 \& \mathrm{C} 21 \mathrm{COM}=\mathrm{S} \& \mathrm{~S} 21 \mathrm{CNR}=20 \& \mathrm{~S} 21 \mathrm{P} 01=0 \& S 21 \mathrm{P} 02=$ $0 \& S 21 \mathrm{P} 03=\mathrm{I}=\& \mathrm{~S} 21 \mathrm{COLORTERMS}=0 \& \mathrm{~S} 21 \mathrm{STR}=$ EJ000019/2013/3

8. Карташова О. Л. Микрофлора кожи человека [Текст] / О. Л. Карташова, Б. Я. Усвяцов. Экология микроорганизмов человека / Под ред. О. В. Бухарина. Екатеринбург: Институт клеточного и внутриклеточного симбиоза, 2006. - С. 61-102.

9. Кордон Т. І. Принципи створення, механізм дії та клінічне застосування пробіотиків (Огляд) [Текст] / 
T. І. Кордон // Ан. Мечниківського інституту. 2014. - № 4. - С. 8-16. - Режим доступу: http:// nbuv.gov.ua/j-pdf/ami_2014_4_3.pdf

10. Краснопольский Ю. М. Пробиотики для терапии и профилактики дисбактериозов кишечника [Електронний ресурс] / Ю.М.Краснопольский // Укр. мед. журн. - 2011. - № 2. - С. 9. Режим доступу: http://doctor.itop.net/ArticleItem.aspx?ArticleId=195

11. Левицкий А. П. Пребиотики и проблема дисбактериоза [Текст] / А. П. Левицкий, Ю. Л. Волянский, К. В. Скидан. - Х.: ЭДЭНА, 2008. - 100 с.

12. Мокрозуб В. В. Ефективність застосування штамів лакто- та біфідобактерій з препаратами цитокінів при експериментальній стафілококовій інфекції [Текст]: автореф. дис. ... канд. біол. наук: 03.00.07 / В. В. Мокрозуб. - Інститут мікробіології і вірусології ім. Д. К. Заболотного НАН України. - К., 2014. - 22 с.

13. Осипенко М. Ф. Применение пробиотиков в лечении патологии внутренних органов [Текст] / М. Ф. Осипенко // Фарматека. - 2005. - № 14. C. 16-20.

14. Пат. 2144954 RU, C 12 N 1/21, A 61 K 35/74 Штамм бактерий Escherichia coli M 17/p Colap, используемый для получения пробиотического препарата [Текст] / [В. А. Лившиц, В. Л. Чеснокова, В В. Алешин и др.]. Заявник В. А. Лившиц. - № 98107308/13.Заявл.: 15.04.1998. Опубл.: 27.01.2000.

15. Похиленко В. Д. Пробиотики на основе спорообразующих бактерий и их безопасность. Обзор [Текст] / В. Д. Похиленко, В. В. Перелыгин // Хим. и биол. безопасность. - 2007. - № 2-3 (32-33). С. 20-41. Режим доступу: http://www.cbsafety.ru/ rus/saf_32_2f.pdf

16. Пробиотики и пребиотики [Електронний ресурс] // Всемирная гастроэнтерологическая организация (WGO). Практические рекомендации. - 2008. Peжим доступу: http://www.gastroscan.ru/literature/ authors $/ 5634$

17. Рыженко С. А. К 100-летию начала исследований пробиотиков И. И. Мечниковым [Електронний ресурс] / С. А. Рыженко // Укр. мед. журн. - 2010. № 1. - С. 5. Режим доступу: http://www.sesobl.dp.ua/ clients/sesdp.nsf/(InfoW)/6895AB6E7938A02AC 22573C00022A37D?opendocument

18. Риженко С. А. Пробиотик «А-бактерин»- уникальное инновационное предложение для оздоровления населения / С. А. Рыженко, Г. Н. Кременчуцкий [Електронний ресурс] Режим доступу: http:// www.sesobl.dp.ua/clients/sesdp.nsf/(InfoW)/ DB6935EB9CC3AAAAC22574A30023BDCA?opendo cument

19. Соловьева И. В. Изучение биологических свойств новых штаммов рода Lactobacillus [Текст] / И. В. Coловьева // Вестник Нижегородского университета им. Н. И. Лобачевского. - 2010. - № 2 (2). С. $462-468$.
20. Солонина Н. Л. Життєздатність та адгезивні властивості пробіотичних штамів мікробів, що входять до складу ліофілізованих комерційних пробіотиків, яких використовують у практиці [Текст] / Н. Л. Солонина // Annals of Mechnikov Institute. 2013. - № 1. - С. 61-65. [Електронний ресурс] Peжим доступу: http://archive.nbuv.gov.ua/e-journals/ AMI/2013_1/13snlzta.pdf

21. Скроцька О. І. Використання рекомбінантних мікроорганізмів для створення сучасних пробіотичних препаратів [Текст] / О. І. Скроцька, С. О. Старовойтова, Ю. М. Пенчук, Я. В. Гавриш // Наук. пр. Нац. ун-ту харч. технол. - 2012. - № 42. - С. 41-46.

22. Старовойтова С. О. Пробіотики - промотори життя XXI століття / С. О. Старовойтова, В. Ю. Горчаков //Наук. вісті НТУУ «КПІ». - 2006. - № 2. - С. 104-114.

23. Старовойтова С. О. Молочнокислі бактерії - біосорбенти важких металів [Текст] / С. О. Старовойтова, Л. Б. Орябінська, В. Ю. Горчаков // Наук. вісті НТУУ «КПІ». - 2008. - № 1. - С. 108-116.

24. Старовойтова С. О. Технологія пробіотиків: [підруч. для студ. ВН3, які навчаються за напрямом підготов. «Біотехнологія»] [Текст] / С. О. Старовойтова, О. І. Скроцька, Ю. М. Пенчук, Т. П. Пирог; Нац. ун-т харч. технол. - К.: НУХТ, 2012. - 318 с.

25. Старовойтова С. О. Сучасні аспекти технології іммобілізованих пробіотиків [Текст] / С. О. Старовойтова // Біотехнол. - 2012. - Т. 5, № 4. - С. 9-20.

26. Старовойтова С. О. Імуномодулюючі властивості бактерій роду Lactobacillus [Текст] / С. О. Старовойтова, Н. О.Тимошок, В. Ю. Горчаков, М. Я.Співак // Мікробіол. журн. - 2009. - Т. 71, № 3. - С. 41-47.

27. Старовойтова С. А. Пробиотики на основе трансгенных микроорганизмов [Текст] / С. А. Старовойтова, О. И. Скроцкая // Biotechnol. Acta. - 2013. Vol. 6, № 1. - C. 34-45.

28. Старовойтова С. А. Огляд міжнародних проектів у галузі мікробної екології людини та створення пробіотиків [Текст] / С. А. Старовойтова // Biotechnol. Acta. - 2013. - Vol. 6, № 3. - C. 121-131.

29. Ткаченко Е. И. Saccharomyces boulardii (Энтерол®) в практике терапевта и гастроэнтеролога / Е. И. Ткаченко, Е. В. Сказываева, Е. Б. Авалуева, С. И. Ситкин // Гастроэнтерол. Санкт-Петербурга. - 2010. № 1. - С. 23-24.

30. Шендеров Б. А. Пробиотики, пребиотики и синбиотики. Общие и избранные разделы проблемы [Текст] / Б. А. Шендеров // Пищевые ингредиенты. Сырье и добавки. - 2005. - № 2. - С. 23-26.

31. Янковский Д. С. Микрофлора и здоровье человека [Текст] / Д. С. Янковский, Г. С. Дымент. - К.: ТОВ «Червона Рута-Турс», 2008. - 552 с.

32. Billoo A. G. Role of a probiotic (Saccharomyces boulardii ) in management and prevention of diarrhoea [Electronic resource] / A. G. Billoo // World J. Gastroenterol. - 2006. - Vol. 12, № 28. - P. 4557-4560. ISSN 
1007-9327. - Access mode: http://www.wjgnet.com/ 1007-9327/12/4557.pdf

33. Characterization Standards for Probiotics [Text] / Guidance for Industry. Early Clinical Trials with Live. Biotherapeutic Products: Chemistry, Manufacturing, and Control Information [DRAFT GUIDANCE]. - University of Maryland School of Medicine. - 2010. - P. 1-17.

34. Ducle H. Characterization of Bacillus probiotics available for human use [Text] / [H. Ducle, H. A. Hong, T. M. Barbosa et al.] // Appl. and Environ. Microbiol. 2004. - Vol. 70, № 4. - P. 2161-2171.

35. Final Report Federal Regulation of Probiotics: An Analysis of the Existing Regulatory Framework and Recommendations for Alternative Frameworks [Text] / Diane E. Hoffmann. - NIH Grant Number: 5R01HG 005171-02. November 15, 2012. - 116 p.

36. ICMR-DBT. Guidelines for evaluation of probiotics in food [Text] / G. S. Toteja // Ind. Council of Med. Res. New Delhi, 2011 [Електроний ресурс]. Режим доступу: www.icmr.nic.in

37. Martinez R. C. R. In vitro evaluation of gastrointestinal survival of Lactobacillusamylovorus DSM 16698 alone and combined with galactooligosaccharides, milk and/or Bifidobacterium animalis subsp. lactis Bb-12 [Text] / R. C. R. Martinez // Int. J. Food Microbiol. 2011. - Vol. 149. - P. 152-158.

38. Pilipenko V. I. Probiotics as signaling molecules: Saccharomyces boulardii [Text] / V. I. Pilipenko // Clin. gastroenterol. and gemetol. - 2008. - № 6. P. 456-462.

39. Probiotics in food Health and nutritional properties and guidelines for evaluation [Text] / World Health Organization. Food and Agriculture Organization of the United Nations. Rome, 2006. - 56 p. - ISSN 0254-4725.

40. Vamanu E. Viability of the Lactobacillus rhamnosus IL1 strain in simulated gastrointestinal conditions [Text] / E. Vamanu, A. Vamanu // Int. J. Pharmacol. 2010. - Vol. 6. - P. 732-737.

41. Venugopalan Veena Regulatory Oversight and Safety of Probiotic Use [Text] / Veena Venugopalan, Kimberly A. Shriner, Annie Wong-Beringer // Emerging Infectious Dis. - November 2010. - Vol. 16, № 11. - P. 1661-1665.

42. Wenner M. Going with his gut bacteria [Text] / M. Wenner // Sci. Amer. - 2008. - July. - P. 90-92.

\section{УДК 616.2:316-092.9:579.861.2}

С. В. Калиниченко, О. О. Коротких, И. Ю. Тищенко

\section{НАРУШЕНИЯ МИКРОЭКОЛОГИИ И ЕЕ СОВРЕМЕННАЯ КОРРЕКЦИЯ (ОБЗОР ЛИТЕРАТУРЫ)}

Необходимость корректировать баланс микробиоценоза - проблема современная и актуальная. Рассмотрен широкий диапазон препаратов (продуктов), которые влияют на различные звенья микроэкологического процесса: пробиотики, препараты на основе инактивированных микроорганизмов, пребиотики, синбиотики, препараты метаболического типа, продукты функционального питания, нутрицевтики. Проанализированы и обоснованы механизмы их действия, актуальность и перспективы использования известных и создание новых препаратов, которые влияют на эндоэкологию и обновляют ее.

Ключевые слова: микрофлора; микроэкология; пробиотики; пребиотики; синбиотики; нутрицевтики; биотерапия; функциональное питание

\section{УДК 616.2:316-092.9:579.861.2}

\section{С. В. Калініченко, О. О. Коротких, І. Ю. Тіщенко}

\section{ПОРУШЕННЯ МІКРОЕКОЛОГІЇ ТА ЇЇ СУЧАСНА КОРЕКЦІЯ (ОГЛЯД ЛІТЕРАТУРИ)}

Необхідність корегувати баланс мікробіоценозу - проблема сучасна та актуальна. Розглянуто широкий діапазон препаратів (продуктів), які впливають на різні ланки мікроекологічного процесу: пробіотики, препарати на основі інактивованих мікроорганізмів, пребіотики, синбіотики, препарати метаболічного типу, продукти функціонального харчування, нутрицевтики. Проаналізовані та обгрунтовані механізми їх дії, актуальність та перспективи використання відомих та створення нових препаратів, які впливають на ендоекологію та оновлюють ії. Ключові слова: мікрофлора; мікроекологія; пробіотики; пребіотики; синбіотики; нутрицевтики; біотерапія; функціональне харчування

Адреса для листування:

61002, м. Харків, вул. Куликівська, 12.

Національний фармацевтичний університет
Надійшла до редакції 21.01.2016 p 